\title{
Contribution of hydrochemistry to the characterization and assessment of groundwater resources: the case of Tebessa alluvial aquifer (Algeria)
}

\author{
NASSIMA SEDRATI \& LARBI DJABRI \\ Department of Geology, Badji Mokhtar - Annaba University, Algeria \\ nassimased@yahoo.fr
}

\begin{abstract}
Assessment of groundwater resources requires the knowledge of geometric and hydrodynamic features. In the Mio-Plio-Quaternary aquifer of the plain of Tebessa (Algeria), the groundwater quality is deteriorating. Different methods using geochemistry (ions $\mathrm{Na}^{+}, \mathrm{Cl}^{-}, \mathrm{SO}_{4}{ }^{2-}, \mathrm{NO}_{3}^{-}$) and conductivity are compared with the hydrogeological information to identify the main processes involved in the increase in pollution. The evaluation for water contamination is based on the method proposed by Tolga et al. (2009) for irrigation waters, and on that proposed by Neubert et al. (2008), for those intended for drinking water supply. This method is a new technique of indexation of water sensitivity to pollution. It combines data from water chemistry and the results obtained by applying the DRASTIC model to the area of study. The obtained maps of sensitivity reveal zones that coincide almost perfectly with those of strong anthropogenic activities. Suitable water management policies are needed to save this unconfined aquifer and provide the data necessary to define the area at increased risk from these phenomena.
\end{abstract}

Key words assessment; water sensitivity; DRASTIC; management; risk; Plain of Tebessa, Algeria

\section{INTRODUCTION}

The study of the vulnerability of groundwater to pollution is an old concept and has been approached by several authors, which had the effect of developing multiple methods of approach, mostly based on the mapping of risk areas. Indeed the study of the vulnerability of groundwater to pollution by mapping began during 1970, when scientists found that the risk of pollution of water resources is acute. It is defined and used in very varied ways (Lallemand Bars and Roux 1989, Lallemand Bars 1994, Gogu and Dassargues 1998). The problem becomes graver for areas with water resources of strategic importance, as is the case for the Tebessa region, Algeria. The basement of the Tebessa plain contains three aquifer water levels of unequal magnitudes: a Triassic formation at Jebel Djebissa, a carbonate formation represented by limestone-marl of the Cretaceous. This formation is very sharp at the edges of the plain, and a large alluvial deposit of Mio-Plio-Quaternary age, which rests on the surface of the plain and Piedmont, especially in reliefs non-conforming with previous formations.

Water from these aquifers is used for all facilities (irrigation, water supply). Due to the absence of water treatment and purification, wastewater is discharged to the ground and percolates into groundwater levels causing water pollution and exposing the population to diseases related to water transmission. This upper aquifer (alluvial deposit) is of low depth (maximum $10 \mathrm{~m}$ ) remains the most exposed to pollution, which is why it is of interest in this study.

\section{STUDY AREA}

\section{Geography}

The study area (Fig. 1) is located in the far east of Algeria, at the "gates" of the Desert, about 230 $\mathrm{km}$ south of Annaba on the Mediterranean coast. The region is bound to the south by the province of El Oued, to the west by Constantine and to the east by Tunisia.

\section{Geology}

The geology of the region (Fig. 2) is characterized by emergent formations of the Quaternary at the centre of the plain; the latter consists of deposits. These deposits are distributed within the lower parts of reliefs and cover large surface areas (plains and present valleys). They are formed of 
limestone crusts, silt debris, gravel and gypsum conglomerates. This material is altered and transported by wind and water action.

The Quaternary aquifer of the continental origin has a thickness of 10 to $30 \mathrm{~m}$. Also note the presence of the Triassic formations, particularly those of Jebel Djebissa. This suggests that sheets of water are subject to salinization caused by these formations. The Turonian, Maastrichtian and Campanian are represented by limestone reliefs constituting the northeastern and southern boundaries of the plain, which also form important groundwater aquifers.

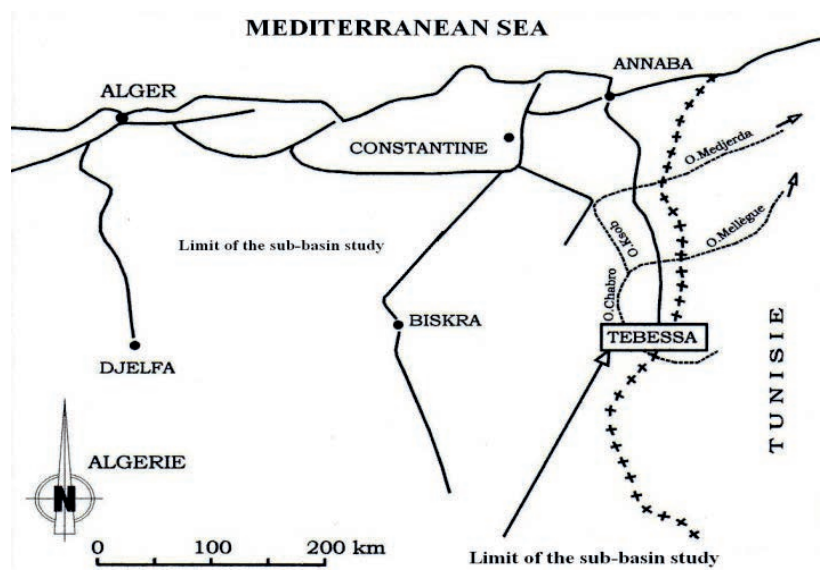

Fig. 1 Location of the study area.

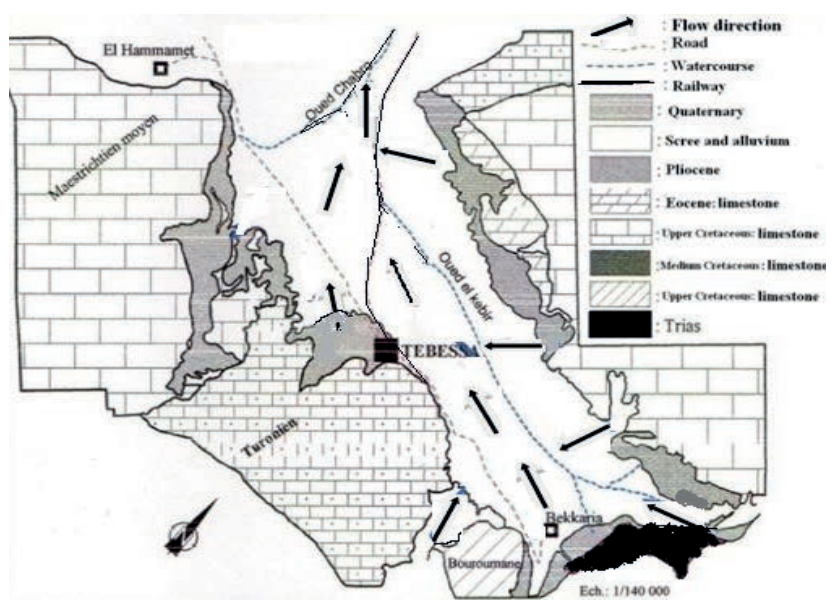

Fig. 2 Geological map and flow direction of the Tebessa plain (Djabri 1987).

\section{Climatology}

The climate of Tebessa is semi-arid, with two rainy periods: from September to November and from February to May. Annual averages of rainfall vary from 307 to $625 \mathrm{~mm}$ for the period 1972-2009 (Ghrieb 2010), evapotranspiration and infiltrations are 749.1 and $6.5 \mathrm{~mm}(1.8 \%$ of precipitation), respectively. The average yearly temperature currently reaches $17^{\circ} \mathrm{C}$ while it was around $15^{\circ} \mathrm{C}$ during $1972-2009$ ). As for the surface flow (El Kebir, Chabro and Ksob), the network allows natural drainage of the plain.

\section{Hydrogeology: Piezometric indications}

In general, the piezometric surface (Fig. 3) has the same morphology as topography. Two major directions of flow: the first east to west direction is from Bekkaria to Tébessa; the second direction is north to south. To the east, the isopièzes curves are generally regular, indicating a hydraulic gradient of the order of 0.05 . In the central area, the curves indicate a low hydraulic gradient of the order of 
0.002. It is thought that the variation of the hydraulic gradient is mainly due to the heterogeneity of the lithology. It was noted that a much accentuated depressive zone was located at the north of Ain chabro. This is generated by the exploitation of drillings and wells in this part, with more than 30 wells in the exploitation listed in the study area. In a large part the waters converge towards Kabir watercourse, which plays the role of a drainage axis at the superficial aquifer.

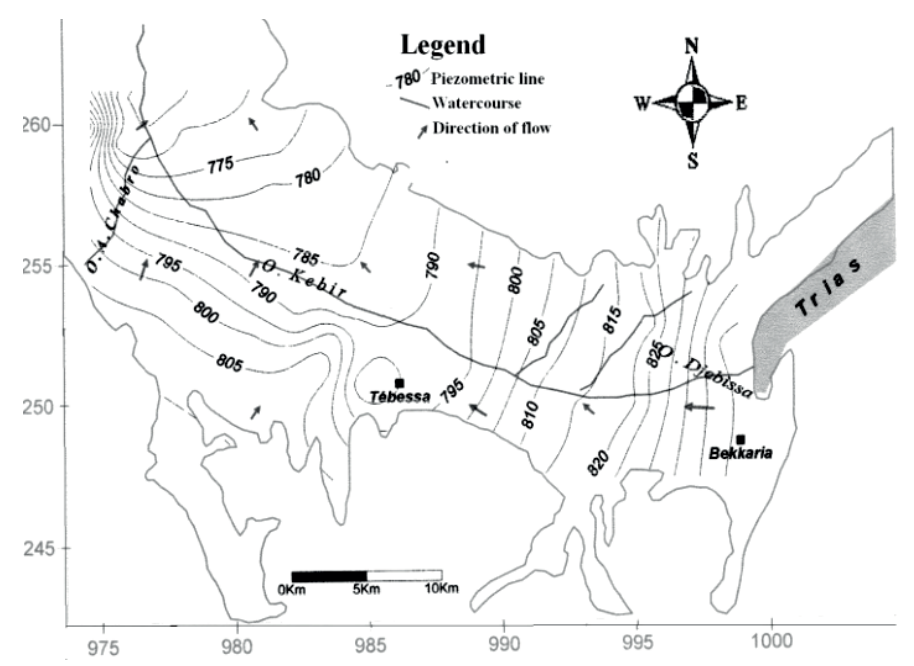

Fig. 3 Piezometric map of Tebessa plain (Ghrieb 2010).

\section{MATERIALS AND METHODS}

To achieve this work we used the results from two methods. The first is the DRASTIC method elaborated by Aller et al. (1987), and the second approach called the index method of sensitivity to pollution, developed by Tolga et al. (2009). The first method is relatively old (1987), and is based on the combination of seven parameters. This method has been successfully tested in different areas of the world (Albinet and Margat 1970).

The DRASTIC method is based upon the results obtained from the cartography of the seven following parameters: D: depth to water; R: net recharge; A: aquifer media; S: soil media; T: topography; I: impact of the vadose zone; C: hydraulic conductivity.

We note that the risk of degradation of groundwater quality is measured by the index (IV), obtained from the DRASTIC method. The assessment of this risk essentially depends on the reliability of the information available. However, the following assumptions are put and must be verified: (i) The DRASTIC method is applicable at the regional scale; (ii) the initial source of pollution is spreading in the middle rather than from the surface; and (iii) the quality of the contaminant does not intervene on degree of vulnerability. It is noted that the estimation of the final index (IV) requires first evaluating the partial DRASTIC index for each of the seven parameters (D, R, A, S, T, I and C).

This partial index is assigned a weight and a coast ranging from 1 to 5 and from 1 to 10 defining their level of vulnerability, respectively (Aller et al. 1987). The DRASTIC index (IV) is then the weighted sum of weight coasts of the seven specific parameters to each hydrogeologic region.

The second approach is based on the calculation sensitivity index of water to pollution (IS). This latter was applied successfully to the aquifer Menderes in Turkey (Tolga et al. 2009).

Which method is the product of the DRASTIC index of vulnerability $(I V)$ and index of water quality $(I Q)$, are given by equation (1):

$I S=I V \times I Q$

The indexing of the sensitivity of the water quality takes into account the water classification into five groups depending on each ion concentration: I: very good water; II: good; III: usable; IV used with prudence; and V: harmful. The limits of each class used for the parameters concerned are listed in Tables 1 and 2. The punctual index quality is calculated using equation (2): 


$$
I Q=\sum_{i}^{n} C i^{2}
$$

The summation is generally considered to be a quality parameter (ions). $\mathrm{Ci}$ is the class of the parameter $i$ (ion) with an integer value between 1 and 5 at a given location. The use of the squared $\mathrm{Ci}$ concentration of each ion allows reinforcement of the effect of class of poor quality.

Table 1 Irrigation water classification (Tolga et al. 2009).

\begin{tabular}{llllll}
\hline Parameter & $\begin{array}{l}\text { Class I (very } \\
\text { good) }\end{array}$ & $\begin{array}{l}\text { Class II } \\
\text { (good) }\end{array}$ & $\begin{array}{l}\text { Class III } \\
\text { (usable) }\end{array}$ & $\begin{array}{l}\text { Class IV (usable with } \\
\text { prudence) }\end{array}$ & $\begin{array}{l}\text { Class V } \\
\text { (harmful) }\end{array}$ \\
\hline $\mathrm{EC}(\mu \mathrm{S} / \mathrm{cm})$ & $0-250$ & $250-750$ & $750-2000$ & $2000-3000$ & $>3000$ \\
$\mathrm{Cl}(\mathrm{mg} / \mathrm{L})$ & $0-142$ & $142-249$ & $249-426$ & $426-710$ & $>710$ \\
$\mathrm{NO}_{3}{ }^{-}(\mathrm{mg} / \mathrm{L})$ & $0-10$ & $10-30$ & $30-50$ & $50-100$ & $>100$ \\
$\mathrm{SO}_{4}{ }^{2-}(\mathrm{mg} / \mathrm{L})$ & $0-192$ & $192-336$ & $336-575$ & $576-960$ & $>960$ \\
$\mathrm{Na}^{+}(\mathrm{mg} / \mathrm{L})$ & $0-69$ & $69-200$ & $200-252$ & & $>252$ \\
\hline
\end{tabular}

Table 2 Drinking water classification (Neubert et al. 2008).

\begin{tabular}{llllll}
\hline Parameter & $\begin{array}{l}\text { Class I (very } \\
\text { good) }\end{array}$ & $\begin{array}{l}\text { Class II } \\
\text { (good) }\end{array}$ & Class III (usable) & $\begin{array}{l}\text { Class IV (usable with } \\
\text { prudence) }\end{array}$ & $\begin{array}{l}\text { Class V } \\
\text { (harmful) }\end{array}$ \\
\hline $\mathrm{EC}(\mu \mathrm{S} / \mathrm{cm})$ & $0-180$ & $180-400$ & $400-2000$ & $2000-3000$ & $>3000$ \\
$\mathrm{Cl}(\mathrm{mg} / \mathrm{L})$ & $0-25$ & $25-200$ & & & $>200$ \\
$\mathrm{NO}_{3}^{-}(\mathrm{mg} / \mathrm{L})$ & $0-10$ & $10-25$ & $25-50$ & & $>50$ \\
$\mathrm{SO}_{4}^{2-}(\mathrm{mg} / \mathrm{L})$ & $0-25$ & $25-250$ & & & $>250$ \\
$\mathrm{Na}^{+}(\mathrm{mg} / \mathrm{L})$ & $0-20$ & $20-200$ & & & $>200$ \\
\hline
\end{tabular}

$E C$, electric conductivity.

\section{RESULTS AND DISCUSSION}

\section{The DRASTIC method}

The vulnerability map obtained by the DRASTIC method (Fig. 4), indicates the presence of three classes of unequal extension vulnerability:

- The low vulnerable area, characterized by a DRASTIC index I smaller than 100 , the extension is low and localizes to the south edge of the field. This area is made of particularly compact and fissured limestone. It is protected from any type of pollution.

- The average vulnerable area, where the index is between 100 and 150, occupies nearly all of the ground. It is characterized by the presence of less or more clay-rich alluvial formations. In this zone, the flow is from east to west. The permeability is about $10^{-5} \mathrm{~m} / \mathrm{s}$.

- The large vulnerable area, for which the DRASTIC index is higher than 150, is situated at the confluence of wadis Chabro and Kebir. This area consists of gravel indicating a very high permeability $\left(10^{-2} \mathrm{~m} / \mathrm{s}\right)$ constituting an accelerator of pollution into deeper aquifers.

\section{The method of Tolga Pusalti}

Chemical analyses used to calculate the quality indices for irrigation and water supply were made in July 2010, thus in the dry season when the water is more highly stressed. The elements in question (the electrical conductivity, $\mathrm{Cl}^{-}, \mathrm{SO}_{4}{ }^{2-}$ and $\mathrm{NO}_{3}{ }^{-}$) have very high concentrations. Moreover, the sensitivity indexing is calculated by taking the product of the DRASTIC vulnerability index $(I V)$ and the index of chemical quality (IQ) of waters (National Agency of Water Resources, campaign 2010, low water period). The $I Q$ is calculated on the basis of the classification proposed by Tolga et al. (2009), for irrigation water, and the one proposed by Neubert et al. (2008) for water intended for drinking water. Two sensitivity maps are developed: the map of the sensitivity index of irrigation water (Fig. 5), and that of water intended for drinking water (Fig. 6). 


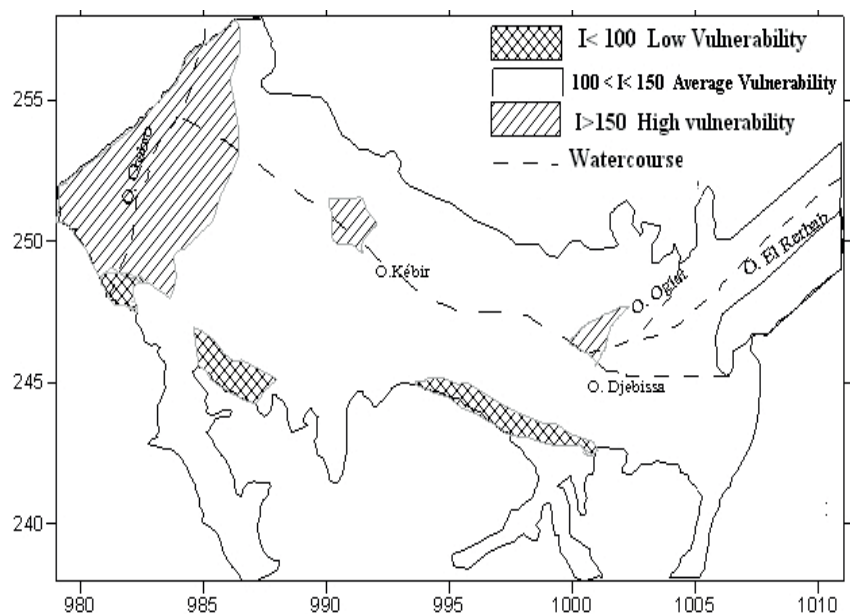

Fig. 4 Vulnerability map of the waters of the Tebessa Plain (DRASTIC) (Djabri 2008).
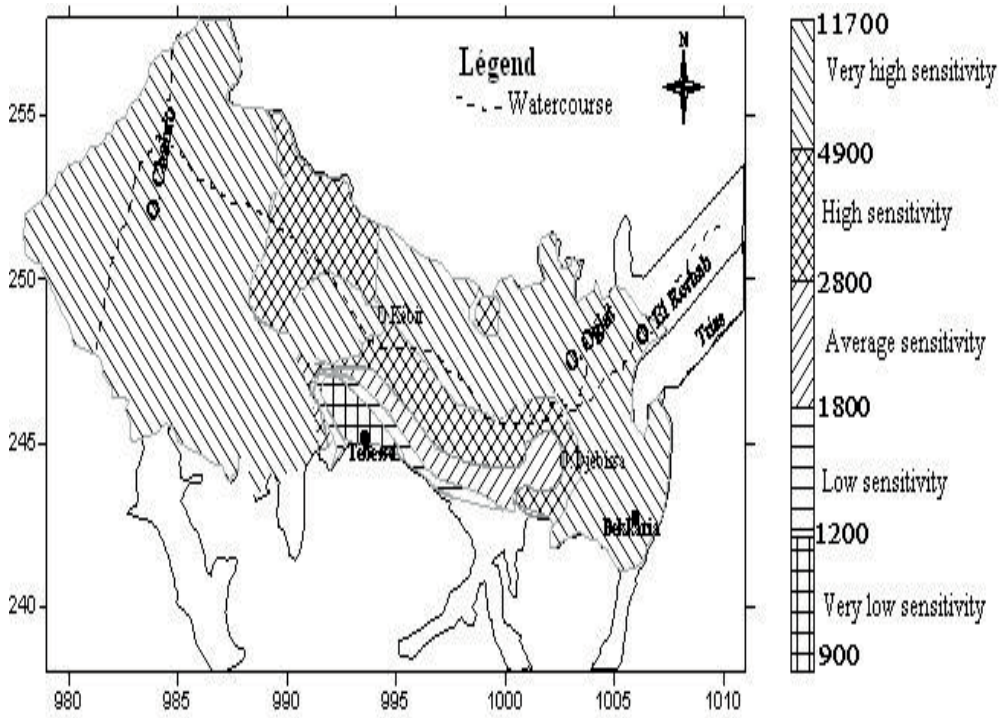

Fig. 5 Map of the sensitivity indexing of irrigation water to the Tebessa Plain.
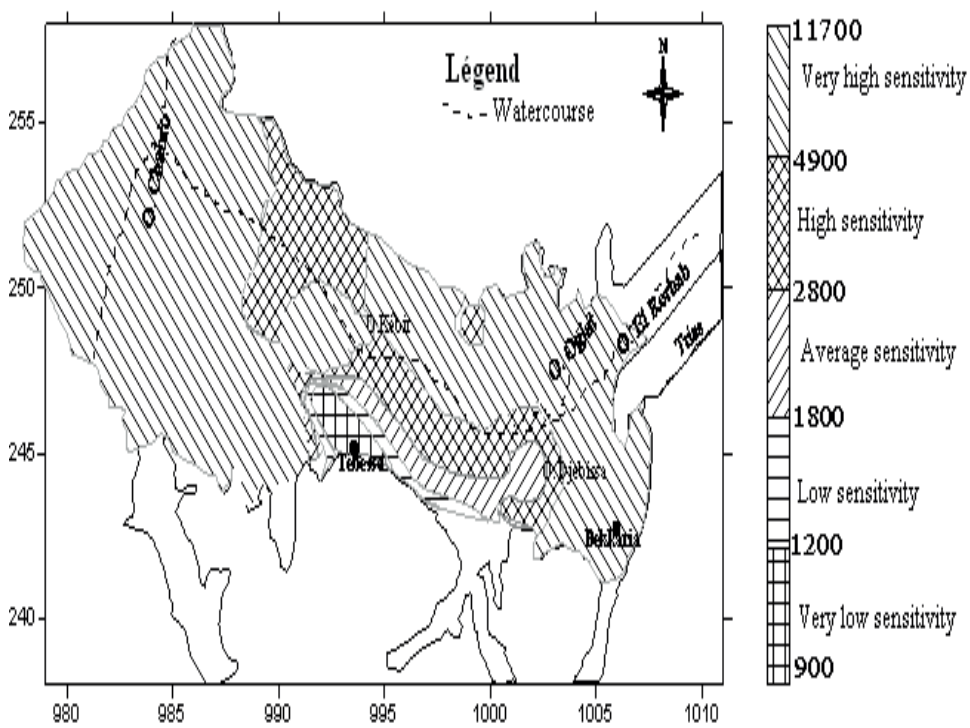

Fig. 6 Map of the sensitivity index of water for the AEP to the Tebessa Plain. 


\section{Map of the sensitivity indexing for irrigation water to the Tebessa Plain}

The map (Fig. 5) reveals that the sensitivity index varies between 1800 and 11700 . The lowest values (between 1800 and 2800) are located in the eastern and southern edges of the plain. These areas are untouched by human activity. The index indicating a high sensitivity (2800-4900) characterizes the Ain Chabro area in this part of the plain, the land is characterized by facilitating flow. Also, this part of the study area is only exploited for the supply of drinking water. Finally, the third area characterized as the area with very high sensitivity, shows indices values between 4900 and 11700 . This area occupies the centre of the plain, and is influenced by the Triassic formations flush Jebel Djebissa. The formations exposed in this section are very heterogeneous (clay, sand), preventing the flow of water and causing an increased risk of pollution by providing wastewater to Tebessa city.

\section{Map of the sensitivity indexing of water for the water supply}

The indices calculated range between 900 and 11700 . Water intended for drinking is characterized, in most of the study area, with a very high sensitivity (Fig. 6). Areas indicating high sensitivity locate the centre of the study area. Areas indicating an average sensitivity to very low are located in a small area south of the Tebessa Plain.

\section{CONCLUSION}

The vulnerability mapping of groundwater to pollution is a methodology that has become necessary to ensure the qualitative management of water resources in relation to various human activities. It therefore appears necessary and vital as this type of maps makes it very easy to identify areas at risk of potential pollution. It will thus serve as a tool for decision support to managers of water resources and will also orientate the planning. In this study we have considered the case of the Tebessa plain.

The observation of results obtained from the combination of the DRASTIC model and method for indexing water quality indicating a vulnerability of groundwater to pollution, particularly in the centre of the plain affected both by the geological formations (Triassic) located at the upstream to edge of Bekkaria and by human activity (soil fertilization and wastewater discharges). Worth noting is that the southern borders of Tebessa city have good quality water, the latter derived from limestone formations present in the area.

\section{REFERENCES}

Albinet, M. and Margat, J. (1970) Cartographie de la vulnérabilité à la pollution des nappes d'eau souterraines. Bull. BRGM (2), Section III, N ${ }^{\circ}$, $13-22$.

Aller, L. et al. (1987) DRASTIC a standardized system for evaluation of ground water pollution, potential using hydrogeology setting .Rapport EPA. NWWA. Ohio. USA, 45.

Djabri, L. (2008) Vulnérabilité des eaux à la pollution dans une zone à climat semi-aride: région de Tébessa (Extrême Est Algérien).Bulletin du service géologique national 19(2), 115-133.

Ghreib, L. (2007) Impact des formations triasiques sur la qualité des eaux et du sol en zone semi aride-cas de la plaine Bekkharia-Tébessa (Extrême Nord-Est Algérien).Mémoire de Magister, Université Badji Mokhtar, Annaba, Algérie, 145170 .

Ghreib, L. (2010) Impact de la minéralisation des formations triasiques sur la qualité des eaux et du sol en zone semi aride-cas de la plaine Bekkharia-Tébessa (Extrême Nord-est Algérien). Thèse de Doctorat, Université Badji Mokhtar, Annaba, Algérie, 245-270.

Gogu, R. and Dassargues, A. (1998) A short review on groundwater vulnerability assessment, basic statements for use in the framework of the cost 620 action. Workshop 18-20 mai. Université de Neuchâtel.

Lallemend-Barres, A. (1994) Normalisation des critères d'établissement des cartes de vulnérabilité aux pollutions. Etude documentaire préliminaire. R37928. BRGM.

Lallemend-Barres, A and Roux, J-C. (1989) Guide méthodologique d'établissement des périmètres de protection des captages d'eau souterraine destinée à la consommation humaine. BRGM manuels et Méthode $n^{\circ} 19$.

Neubert, M. et al. (2008) A GIS based susceptibility indexing method for irrigation and drinking water management planning: Application to Chebba - Melloulich aquifer. Tunisia 5-10.

Tolga, P. et al. (2009) Susceptibility indexing method for irrigation water management planning: Applications to K. Menderes river basin, Turkey.Department of Geological Engineering, Middle East. Journal of Environmental Management, Volume 90(1), 341-347. 